\title{
Bacterial colonization of winter flounder Pseudopleuronectes americanus fed live feed enriched with three different commercial diets
}

L. H. Seychelles ${ }^{1}$, C. Audet ${ }^{1,{ }^{*}}$, R. Tremblay ${ }^{1}$, K. Lemarchand ${ }^{1}$, F. Pernet ${ }^{2}$

\footnotetext{
${ }^{1}$ Institut des sciences de la mer de Rimouski, Université du Québec à Rimouski, Rimouski, Québec, Canada

${ }^{2}$ Laboratoire Environnement-Ressources du Languedoc-Roussillon, IFREMER, Sète Cedex, France

*: Corresponding author : Céline Audet, Tél. : (418) 723-1986, ext. 1744 ; Fax : (418) 724-1842. ;

email address : celine audet@uqar.qc.ca
}

\begin{abstract}
:
The proliferation of bacteria in intensive aquaculture systems may be responsible for poor growth and mass mortality of marine fish larvae. Essential fatty acids provided in the diet could protect larvae by modulation of the immune response via arachidonic acid (AA) and eicosapentaenoic acid (EPA). Winter flounder Pseudopleuronectes americanus larvae were fed rotifers Brachionus plicatilis enriched with three commercial diets containing different fatty acid profiles. Bacterial colonization on the gills and skin and in the intestinal lumen was evaluated at the end of the rotifer feeding period (day 26), and growth was surveyed until metamorphosis. At 26 days post hatching, larvae fed rotifers containing the higher AA content and with a higher docosahexaenoic acid (DHA) to EPA ratio showed better growth and the lowest bacterial colonization of the intestinal lumen compared to larvae fed rotifers with the lowest AA and DHA : EPA levels. AA had been selectively incorporated into the polar lipids of larvae fed the rotifers enriched with the three diets. This is the first study in winter flounder larvae to report a link between different commercial rotifer enrichments and bacterial density in intestinal lumen.
\end{abstract}

Keywords : bacteria, colonization, fatty acids, live feed, winter flounder. 


\section{Introduction}

There is an increasing demand for fry from farmed fish, and most are already produced in intensive rearing installations. However, intensive rearing of marine fish larvae may lead to microbial problems, resulting in poor growth and mass mortality (Muroga 1987; Nicolas 1989; Munro et al. 1994). The artificial aquaculture environment is characterized by a decrease in water quality and an accumulation of organic matter that promote proliferation of opportunistic bacteria (Skjermo \& Vadstein 1999; Olafsen 2001). Pathogens often arise in the early stages of larval rearing because the culture of small and sensitive marine larvae often involves a period with no or low water exchange (e.g., feeding period) (Skjermo \& Vadstein 1999).

The bacterial population in the water significantly affects the bacteria colonizing live prey (Nicolas 1989) and in fish digestive tracts (Munro et al. 1994; Ringø et al. 1996; Ringø \& Birkbeck 1999); this has been observed in flatfish larvae such as turbot Scophthalmus maximus (Nicolas 1989) and summer flounder Paralichthys dentatus (Eddy \& Jones 2002). Marine larvae must take in water to maintain their osmotic balance, even before mouth opening (Reitan et al. 1998), so small amounts of bacteria could enter the digestive tract when water is ingested for osmoregulation (Tytler 1988; Hansen \& Olafsen 1999; Ringø \& Birkbeck 1999); this facilitates the inoculation of opportunistic bacteria in larvae. Thus gills and intestinal surfaces are important sites of bacterial colonization. Nicolas et al. (1989) showed that prior to exogenous feeding, turbot larvae had internal microflora similar to that of the water. Bacterial invasion through the skin is also possible (Vadstein 1997). A way to decrease the impact of pathogenic bacteria is to stimulate immune function by nutritional supplements. Dietary lipids and their constituent fatty 
acids are fundamental for very small and rapidly developing larvae as they supply energy and cell components for structural membranes (Sargent et al. 2002).

Several studies have characterized the bacterial flora associated with cold-water marine fish larvae without taking into account larval diet (review by Hansen \& Olafsen 1999). In addition, little information is available on the impact of commonly used enrichment media on the intestinal microbiota of fish larvae (Korsnes et al. 2006) although a link has been revealed between dietary essential fatty acids and immune function in fish: essential fatty acids and their derivative products, eicosanoids, are highly biologically active and are involved in immunity (Tocher 2003).

Experiments conducted on channel catfish Ictalurus punctatus fed a diet enriched with $n-3$ fatty acids showed a positive correlation with macrophage activity while excess levels of highly unsaturated $n-3$ fatty acids may not be as effective (Sheldon \& Blazer 1991). Similar positive effects were observed in rainbow trout Onchorhynchus mykiss (Kiron et al. 1995). These authors showed that dietary levels of $n-3$ polyunsaturated fatty acids (PUFA) affect bacterial infections and leucocyte mobility. Experiments on EFA deficiencies conducted on gilthead sea bream Sparus aurata juveniles showed a decrease in both neutrophil activity and lymphocyte abundance (Montero et al. 2004). Although the role of dietary lipids in fish immunity is not fully understood, they may modulate the immune response by changing the physical properties of immune cell membranes and cell membrane interactions (e.g., phagocytosis, antigen-antibody connections) through eicosanoid production from arachidonic acid (20:4n-6, AA) and eicosapentanoic acid (20:5n-3, EPA). 
The main objective of this work was two-fold: to study bacterial colonization of winter flounder Pseudopleuronectes americanus larvae fed rotifers enriched with three different diets and to examine the fatty acid dynamics in larval membranes and lipid reserves. Winter flounder larvae were fed rotifers that had been enriched with three different commercial formulations for a period of 22 days to obtain rotifers with different contents of AA and 22:6n-3, docosahexaenoic acid (DHA) to EPA ratio.

\section{Material and Methods}

\section{Larvae: culture and sampling}

All experiments were conducted at the Station aquicole de Pointe-au-Père (UQAR, 48 ${ }^{\circ} 7^{\prime}$ $\mathrm{N} ; 68^{\circ} 32^{\prime} \mathrm{W}$, Québec, Canada). Larvae were obtained using a reproduction method described previously (Ben Khemis et al. 2000). Newly hatched (day 0) flounder larvae were reared in six 57-1 cylindro-conical polyethylene tanks at a rearing density of 250 larvae $1^{-1}$ from April to August 2004. Tanks were supplied with filtered seawater $\left(10 \mu \mathrm{m}, 8.7 \pm 0.5^{\circ} \mathrm{C}, 27 \pm 1 \mathrm{~g} \mathrm{~L}^{-1}\right)$ with aeration; water temperature was maintained at $10^{\circ} \mathrm{C}$ and the photoperiod at $12 \mathrm{~L}: 12 \mathrm{D}$. At mouth opening, larvae were fed one of the three following formulations: (1) rotifers (Brachionus plicatilis) enriched with Culture Selco 3000 (SEL), (2) rotifers enriched with DHA protein Selco (DPS) (both from INVE Aquaculture, Grantsville, UT, USA), and (3) rotifers enriched with AlgaMac-2000 (ALG) (Aquafauna Bio-Marine, Hawthorne, CA, USA). The compositions of the three media used were available from their manufacturers $\left(S E L\right.$ : crude proteins $=400 \mathrm{~g} \mathrm{~kg}^{-1} \mathrm{dry}$ matter, lipids $=80 \mathrm{~g} \mathrm{~kg}^{-1}$ dry matter, DHA:EPA $=1 ;$ DPS: crude proteins $=270 \mathrm{~g} \mathrm{~kg}^{-1}$ dry matter, lipids $=290 \mathrm{~g} \mathrm{~kg}^{-1}$ dry matter; DHA:EPA $=2 ; A L G$ : crude proteins $=200 \mathrm{~g} \mathrm{~kg}^{-1}$ dry matter, lipids $=380 \mathrm{~g} \mathrm{~kg}^{-1}$ dry matter, DHA:EPA = 36). The $A L G$ diet contains a relatively high level of $\mathrm{n}-6$ 
DPA (22:5n-6), which is generally retroconverted to AA in rotifers (Koven et al. 2001; Bransden et al. 2004; Park et al. 2006; Parrish et al. 2007). Rotifer lipid and fatty acid compositions were obtained from a previous experiment (Vaillancourt 2008) conducted in our laboratory using the same enrichment protocol (Table 1). Rotifers were supplied to flounder larvae in excess and their density was maintained at 15-20 rotifers larva ${ }^{-1}$, according to Laurence (1977). Two larval tanks were used for each type of rotifer enrichment.

At hatching (day 0), yolk-sac larvae were placed in rearing tanks. Tank water was continuously renewed for 4 days without food addition, until mouth opening. After mouth opening, the water supply was stopped each day for 12 hours while a pseudo-green-water preparation (a mixture of Isochrysis galbana, Pavlova lutheri and Nannochloropsis oculata) was added to each tank for larval feeding. At the end of the day, water circulation resumed, allowing complete renewal of the tank water during the night. Larvae were sampled with empty stomachs before mouth opening at 4 days post-hatching (dph) and again at 15 and $26 \mathrm{dph}$ as well as at metamorphosis (38 to $46 \mathrm{dph}$ ). On day 26, larvae were first weaned onto larger prey (Artemia franscicana) and then fed a formulated diet (Lansy $\mathrm{Cw}$ 1/8, INVE Aquaculture), a diet designed for weaning cold-water marine fish larvae (DHA: $118 \mathrm{~g} \mathrm{~kg}^{-1}$, EPA: $73 \mathrm{~g} \mathrm{~kg}^{-1}$, AA: $11 \mathrm{~g} \mathrm{~kg}^{-1}$, ALA: $39 \mathrm{~g} \mathrm{~kg}^{-1}$ of total fatty acids). Prey concentration was adjusted twice a day to maintain constant prey levels.

At 26 dph, i.e., at the end of the rotifer feeding period, ten larvae were fixed with $10 \%$ formaldehyde ( $\geq 24 \mathrm{~h}$ at ambient temperature) for light microscopy observations. Fixed larvae were then dehydrated in an ascending series of ethanol solutions and embedded in methacrylate resin. Tissues were sectioned ( $3 \mu \mathrm{m}$ thickness) with a Supercut Reichert-Jung model 2050 
(Cambridge Instruments GmbH, Germany); sections were mounted on glass slides and stained with a Gram staining kit (\#77730, Sigma-Aldrich, Oakville, ON, Canada). Sections were examined and photographed under 1000× (Olympus BX41, W. Carsen Co., Ltd., Don Mills, ON, Canada). The occurrence of bacteria was determined and quantified in gut lumen and on gill and fin surfaces (Figure 1). Bacterial density was calculated within intestinal lumen (bacteria $\mathrm{mm}^{-2}$ ), and bacteria:tissue area proportions were calculated on gills and fins with Image Pro Plus software v5.1 (Media Cybernetics, Silver Spring, MD, USA). Observations were made randomly on 20 larvae for each of the three treatments. Three sections were observed for each individual for each tissue studied.

Ten larvae from each tank were collected for standard length and maximal width ( $\pm 0.1 \mathrm{~mm})$ measurements at $4,15,26,38$, and $45 \mathrm{dph}$. To make measurements easier on day 4 larvae, one drop of $37.6 \%$ formalin was added and data were corrected using the Hjörleifsson \& Klein-MacPhee (1992) equation developed on winter flounder. Larvae surviving until metamorphosis were placed in one of the duplicate tanks of either the $A L G$ or DPS treatment. We encountered a problem of water supersaturated in nitrogen, which prevented us from collecting data in the other tanks.

\section{Bacterial analysis}

Water from each tank $(9 \mathrm{ml})$ was sampled before the pseudo-green water was added then fixed in $2 \%$ formaldehyde (neutral $\mathrm{pH}$ ) on 4 (before mouth opening), 15, 26, 38 and 46 dph to determine the total number of bacteria using flow cytometry. Samples were frozen at $-80^{\circ} \mathrm{C}$ until analysis. The total abundance of bacteria was determined using an Epics Altra flow cytometer 
(Beckman-Coulter, Mississauga, ON, Canada) equipped with a $488 \mathrm{~nm}$ argon laser operated at $15 \mathrm{~mW}$. A $1 \mathrm{ml}$ subsample was incubated with $0.25 \mu \mathrm{l}$ of SYBR Green I (Molecular Probes Inc., Oregon, USA) for $30 \mathrm{~min}$ at room temperature in the dark. Fluorescent beads $(10 \mu 1,1 \mu \mathrm{m}$ diameter) were added to each sample as an internal standard (Lebaron et al. 2002). Total abundances of bacterial sub-populations with high and low nucleic acid contents (HNA and LNA respectively) were graphically discriminated and enumerated (Lebaron et al. 2002) using right angle light scatter (SSC, related to cell size) and the green fluorescence of nucleic acid-bound SYBR Green I measured at $525 \pm 5 \mathrm{~nm}$. On day 46, culturable bacteria associated with rearing water were characterized after $24 \mathrm{~h}$ of incubation in darkness at $20-25^{\circ} \mathrm{C}$. Bacteria were quantified as colony-forming units (CFU) using selective (thiosulfate-citrate-bile salts-sucrose, TCBS, Merck KgaA, Darnstadtm Germany) and non-selective (marine agar) media to estimate Vibrio spp. and heterotrophs respectively.

\section{Lipid analysis}

For lipid analysis, larvae were randomly sampled in each tank and individually rinsed three times in Millipore-filtered seawater. They were pooled (60 larvae for 4, 15, and $26 \mathrm{dph}$ and 40 larvae for 38 and $46 \mathrm{dph}$ ) to reach a sample dry mass of $\sim 0.8 \mathrm{mg}$ and frozen at $-80^{\circ} \mathrm{C}$. Lipid extraction was performed using a modified Folch procedure (Folch et al. 1957). Chloroform was substituted by dichloromethane (Chen et al. 1981) for a final dichloromethane:methanol:potassium chloride volume ratio of 2:1:0.6. The homogenates were mixed and centrifuged twice at $432 \mathrm{~g}$ for 2 min to obtain a biphasic system. After each centrifugation, the lipid fraction was removed and transferred to a clean tube. The solvent was evaporated under nitrogen flow and lipids were dissolved in $100 \mu \mathrm{l}$ of $\mathrm{CH}_{2} \mathrm{Cl}_{2}$. For lipid class 
determinations, a $2 \mu 1$ aliquot of each extract was used. Extracts were spotted onto S-III Chromarods (Iatron Laboratories, Tokyo, Japan); classes were separated using four solvent systems, as described in Parrish (1999), and determined by flame ionization detection using an Iatroscan MK-6s (SES GmbH - Analytical Systems, Bechenheim, Germany). The four solvents were 1) hexane:diethyl ether:formic acid (99:1:0.05), 2) a mix of hexane:diethyl ether:formic acid (80:20:0.1), 3) 100\% acetone, and 4) dichloromethane:methanol:water (5:4:1).

Lipids were fractionated into neutral lipids (NL, including triacylglycerol [TAG], free fatty acids and sterols) and polar lipids (PL, including mainly phospholipids and minor amounts of glycolipids) using column chromatography on silica gel hydrated with $6 \%$ water. The $100 \mathrm{mg}$ columns were preconditioned with $1 \mathrm{ml}$ of methanol and $1 \mathrm{ml}$ of chloroform. Aliquots of $300 \mu \mathrm{g}$ of lipids were loaded onto the solid-phase extraction column. Samples were gently drawn into the solid phase under slight vacuum $\left(\sim 1 \mathrm{ml} \mathrm{min}^{-1}\right)$. Columns were washed with $1 \mathrm{ml}$ chloroform:methanol (98:2 v/v) to elute neutral lipids as described by Pernet et al. (2006).

For fatty acid analyses, lipid extracts were dried and fatty acid methyl esters (FAMEs) were prepared by transesterification with $12 \%$ borontrifluoride $\left(\mathrm{BF}_{3}\right)$ in methanol at $100^{\circ} \mathrm{C}(\mathrm{AOCS}$ 1989). FAMEs were run on a SRI 8610C gas chromatograph (SRI, Torrance, CA, USA) equipped with a DB-Wax fused-silica capillary column $(30 \mathrm{~m} \times 0.25 \mathrm{~mm}$ I.D., $0.25 \mu \mathrm{m}$ film thickness; Agilent, Bellfonte, PA, USA). Hydrogen was used as the carrier gas (flow velocity: 80 $\mathrm{cm} \mathrm{s}^{-1}$ at $145^{\circ} \mathrm{C}$ ). FAMEs were directly introduced into a glass liner (uniliner, drilled, $4 \mathrm{~mm}, 6.3$ $\mathrm{mm} \times 78.5 \mathrm{~mm}$; Restek, Bellfonte, PA, USA) maintained at $300^{\circ} \mathrm{C}$ and 40 psi internal pressure for $4 \mathrm{~min}$ to ensure a complete transfer of the vapour sample onto the GC column. To avoid 
discrimination against high boiling point compounds during injection, the syringe was filled with hexane, followed by $2 \mu \mathrm{L}$ air, $1 \mu \mathrm{L}$ sample and another plug of air (sandwich injection). The temperature was initially held at $58^{\circ} \mathrm{C}$ for $4 \mathrm{~min}$ at $40 \mathrm{psi}$ followed by a series of temperature ramps: $20^{\circ} \mathrm{C} \min ^{-1}$ to $170^{\circ} \mathrm{C}$ at $20 \mathrm{psi} ; 1^{\circ} \mathrm{C} \min ^{-1}$ to $180^{\circ} \mathrm{C}$; and finally $2^{\circ} \mathrm{C} \min ^{-1}$ to $220^{\circ} \mathrm{C}$, where it was held for $5 \mathrm{~min}$. The FID system was maintained at $260^{\circ} \mathrm{C}$. FAMEs were identified by comparison of retention times with known standards-a 37-component FAME mix and menhaden oil—and further quantified using nonadecanoic acid (19:0) as an internal standard (Supelco, Bellfonte, PA, USA). Chromatograms were analyzed using integration software (Peak Simple version 3.29, SRI, Torrance, CA, USA).

\section{Statistical analysis}

Statistical analyses were done using STATISTICA software (Tulsa, OK, USA) version 6.0 $(\alpha=0.05)$. Normality of the data was examined using the Kolmogorov-Smirnov test. Significant differences among larviculture treatments were tested using one- or two-way analyses of variance (ANOVAs) for total bacteria in tank water, CFU counts, total length and width, and lipid classes; fatty acids were tested using multiple analysis of variance (MANOVA). Homoscedasticity was tested with the Brown-Forsythe test (Zar 1999). For subsequent multiple comparisons, Tukey tests or Tukey tests for unequal $n$ were performed. The Games \& Howell test was used when the homoscedasticity condition was not met.

\section{Results}

At the end of the rotifer feeding period ( $26 \mathrm{dph})$, bacterial density in the intestinal lumen was six-fold lower $\left(900 \pm 1300\right.$ bacteria per $\mathrm{mm}^{2}$ [mean $\left.\left.\pm \mathrm{sd}\right]\right)$ in larvae fed rotifers enriched with 
the $A L G$ diet than in larvae fed rotifers enriched with the DPS and $S E L$ diets $\left(5.0 \pm 5.610^{3}\right.$ bacteria $\left.\mathrm{mm}^{-2}\right)$. We observed no difference in the bacterial colonization of the gills $(3.0 \pm 4.6 \%)$ and fins $(23.4 \pm 13.4 \%)$ among the three larval treatments (Table 2).

Bacterial cell abundance in the tank water, which was determined by flow cytometry, was constant during the experiment ( 4 to $46 \mathrm{dph}$ ) and similar among the three larviculture treatments, with an average of $4.810^{5}$ bacteria $\mathrm{ml}^{-1}$. Two bacterial populations were observed, some with high and some with low nucleic acid contents (HNA and LNA respectively). The HNA and LNA cell abundance and \% HNA (average of 71.5\%) remained constant during the experiment.

At metamorphosis (46 dph), we observed similar mean counts of Vibrio $\left(49.7 \pm 21.2 \mathrm{CFU} \mathrm{ml}^{-1}\right)$ and culturable bacteria $\left(551.1 \pm 412 \mathrm{CFU} \mathrm{ml}^{-1}\right)$ in the rearing water among feeding treatments. Although the ANOVA indicated a significant treatment effect for the number of heterotrophic bacteria in tank water at $46 \mathrm{dph}$, no significant difference was detected with the post-hoc test (Games \& Howell). The Vibrio index, calculated as the geometric mean of colony-forming units (CFU) on selective medium (TCBS) divided by the geometric mean of CFU on marine agar, was $0.10 \pm 0.01,0.07 \pm 0.00$ and 0.07 for tank water in the $S E L, D P S$ and $A L G$ treatments respectively.

At $26 \mathrm{dph}$, the relative proportions of triacylglycerol (TAG) were low and similar in larvae from the three dietary treatments (Table 3). At $46 \mathrm{dph}$, the TAG proportion was higher in larvae previously fed rotifers enriched with the $A L G$ diet compared to larvae from the $S E L$ treatment. 
From day 15 to 26, we observed accumulations of AA in the NL that were twice as high in larvae fed rotifers enriched with the $A L G$ diet compared to larvae fed the other two diets (Figure 2A). The PL fraction of AA was similar among treatments (Figure 2B). The relative proportion of AA in the PL fraction dropped by 2.5 times between day 26 and day 46 and was highest in larvae fed the $A L G$ diet. The same pattern was observed in NL at metamorphosis. From 4 to $26 \mathrm{dph}$, the EPA proportion in NL decreased slightly and was significantly higher in larvae fed rotifers enriched with DPS than in larvae that had the SEL diet (Figure 2C). From 4 to $26 \mathrm{dph}$, EPA levels in PL were similar to those in NL, with the lowest EPA level observed at 26 dph in PL of larvae fed the $A L G$ diet (Figure 2D). At 38 and 46 dph, the EPA content in NL decreased to around $2 \%$ of the TFA and to an average of $6 \%$ of the TFA in PL. Before mouth opening (4 dph), the DHA proportions in NL and PL were similar among treatments (Figure 2E \& F). The highest DHA level was observed in larvae fed $A L G$ at 15 and at 26 dph in both NL and PL. In larvae fed rotifers enriched with $A L G$, we observed accumulations of 22:5n-6 (n-6 DPA) in NL and PL that represented more than $6.5 \%$ of the TFA (Table 4).

From 15 to 26 dph, PUFA content in both NL and PL was higher in larvae fed the $A L G$ diet than in those of the SEL treatment (Table 4) and was higher at $46 \mathrm{dph}$ in NL from larvae fed the $A L G$ diet than in those fed the two other diets (Table 4). From 15 to $26 \mathrm{dph}$, the relative proportion of monounsaturated fatty acids (MUFA) was the lowest in the NL and PL from larvae fed the $A L G$ diet. Globally, MUFA content increased in NL and PL of all larvae up to 26 dph whereas the proportion remained constant in the PL fraction of larvae fed the $A L G$ diet. The relative percentage of saturated fatty acids (SFA) in the NL and PL of larvae decreased at $26 \mathrm{dph}$ and was higher in the NL of larvae fed the $A L G$ diet than in those fed the DPS diet from 15 to 26 
dph. After the beginning of co-feeding, the relative proportion of linolenic acid reached 18 to $23 \%$ of the TFA at $38 \mathrm{dph}$ in NL and PL respectively (Table 4).

On day 26, larvae from the $A L G$ diet were longer than those from the $S E L$ diet (Figure 3). On day 46, all larvae had reached similar total lengths. Total widths were similar among larviculture treatments on day 26 (data not shown). Larval survival rates from the $A L G$ and $D P S$ treatments were 11.1 and $16.6 \%$ respectively and there was no statistical difference between treatments.

\section{Discussion}

As early as the time of mouth opening, winter flounder larvae have been shown to be equipped with enzymes involved in lipid digestion (Murray et al. 2003), highlighting the importance of dietary lipids for larval growth. Arachidonic acid seems to be an important fatty acid for winter flounder larvae, as they appear to have the ability to selectively incorporate dietary AA into their cellular membranes. AA has been shown to be highly conserved in conditions of dietary deficiency (Bell \& Sargent 2003) in the larvae of several flatfish species such as turbot (Rainuzzo et al. 1994), yellowtail flounder Limanda ferruginea (Copeman \& Parrish 2002), and summer flounder Paralichthys dentatus (Willey et al. 2003).

Although we observed a higher relative percentage of AA in the NL of larvae fed rotifers containing a higher relative level of AA, no parallel increase was detected in PL. However, studies have shown that an increased AA content in the PL of gilthead sea bream Sparus auratus larvae was related to an increase in the dietary AA level (Bell et al. 1995; Bessonart et al. 1999). 
The same phenomenon was observed for EPA in turbot larvae (Reitan et al. 1994). The fatty acid composition of NL generally reflects that of the diet while the fatty acid composition of PL is more strongly regulated and reflects membrane requirements (Sargent et al. 2002). We suggest that the relative AA level (6.6\% of TFA) reached in the cellular membranes of 26 dph winter flounder larvae could be sufficient to sustain larval development.

The lower bacterial density in intestinal lumen was correlated with the dietary treatment that resulted in a higher AA level and higher DHA to EPA ratio in rotifers ( $A L G$ treatment). The higher total length observed in winter flounder larvae of the $A L G$ treatment suggests that the bacteria associated with the intestinal lumen were not pathogenic. High standard deviations observed for bacterial density data in intestinal lumen are indications of great differences among larvae from each treatment. This variability was also observed in intestinal flora of tilapia (Oreocrhomis mossambicus), carp (Cyprinus carpio) and goldfish (Carassius auratus) (Asfie et al. 2003). Using four commercial enrichments for rotifers (Algamac 2000, AquaGrow Advantage [Advanced Bionutrition Columbia, USA], Marol E [SINTEF, Trondheim, Norway] and Protein Selco [INVE, Baasrode, Belgium]), Korsnes et al. (2006) observed an effect on bacterial colonization in the gastro-intestinal tracts of cod Gadus morhua larvae as well as on the bacterial concentration in enrichment cultures. As in our study, these results suggest that the different rotifer enrichments probably affected the number of colony-forming bacteria in the larval gastrointestinal tract.

When considering the fact that classic culture methods only detect $0.1-1 \%$ of total marine bacteria (Vadstein et al. 2004), our total bacterial enumerations in larval tank water using flow cytometry were low compared to values obtained in other studies using the classic culture 
methods. Several studies have reported low levels of Vibrio in rotifer rearing (Verdonck et al. 1997; Skjermo \& Vadstein 1999). The low levels of Vibrio in larval tanks during the rotiferfeeding period could be explained by the use of microalgae, both as food for rotifers and as green water in the larval rearing tank. The addition of algae to the water in fish tanks can considerably alter the composition of the bacterial flora associated with rearing water, larval skin and gut (Skjermo \& Vadstein 1993) and can prevent Vibrio proliferation (Salvesen et al. 1999). Pavlova lutheri and Isochrysis galbana, which were present in the pseudo-green water used in our experiment, have been shown to increase the diversification of bacterial communities (Støttrup \& McEvoy 2003). A larger fraction of slow growers and fewer opportunistic (potentially pathogenic) fast growing bacteria were observed compared to larval rearing in clear water. The Vibrio indexes of tank water at $46 \mathrm{dph}(0.07-0.15)$ were lower than the value of 0.24 observed by Eddy \& Jones (2002) on summer flounder larvae of a similar stage.

The low levels of total culturable heterotrophic bacteria and Vibrio that we observed could be due to the fact that the bottom of the larval rearing tank was cleaned at regular intervals from 26 to 46 dph, thus Vibrio, which survive and proliferate in fish feces (Olsson et al. 1998), could have been partially eliminated. In addition, the Artemia used in this study were non-enriched and harvested in $0.2 \mu \mathrm{m}$ prefiltred seawater. Ritar et al. (2004) observed that the bacteria load associated with Artemia enriched with Algamac was six times higher as early as $6 \mathrm{~h}$ after enrichment compared to those enriched with oil emulsion and Chaetoceros muelleri.

In our study, tank conditions could be inadequate for the growth of bacteria associated with live prey (rotifers and Artemia). Thus, winter flounder larvae were probably exposed to low 
levels of opportunistic bacteria in tank water before and after weaning onto the Artemia and dry diet. This was shown by the constant abundance of high and low nucleic acid bacteria and the low Vibrio index observed at $46 \mathrm{dph}$. However, bacteria associated with live feed is the major influx to tank water and hence to the intestinal microbiota of larvae (Skjermo \& Vadstein 1993; Munro et al. 1994; Makridis et al. 2000; Jensen et al. 2004). Bacteria associated with individual rotifers have been shown to be active and able to grow (Nicolas 1989). Artemia can have high Vibrio levels (Tanasomwang \& Muroga 1988; Tanasomwang \& Muroga 1989; Verschuere 1997; Olsen et al. 1999; Olsen et al. 2000; Eddy \& Jones 2002), and its use as a feed for marine fish larvae has been shown to coincide with an increase in total bacteria and specific Vibrio abundance in the water, as recently observed by Plante et al. (2007).

At $26 \mathrm{dph}$, larvae fed rotifers containing the highest relative AA level and DHA:EPA ratio were longer than larvae fed SEL-enriched rotifers. Recently, Garcia et al. (2008) observed a higher specific growth rate in cod larvae fed $A L G$-enriched Artemia compared to those fed AquaGrow Advantage. Studies have demonstrated the ability of AA to enhance larval fish growth in the presence of high dietary DHA to EPA ratios (Bessonart et al. 1999; Willey et al. 2003). Juvenile turbot fed pure AA and DHA showed higher growth when fed a diet containing just AA (Castell 1994).

After the beginning of weaning onto non-enriched Artemia and the dry diet, we observed a decrease in the relative proportion of EFAs in all larvae. The decrease in essential fatty acids in both neutral and polar lipids reflects a problem during weaning. The concomitant increase in linolenic acid in both larval neutral and polar lipids suggests that the flounder larvae could not assimilate the dry diet (which was characterized by low levels of linolenic acid [3.8\% of TFA], 
and relatively high levels of PUFA [38.2\% of total fatty acids]) but could profit from the nonenriched Artemia (which have high levels of linolenic acid).

\section{Acknowledgments}

We greatly appreciate the technical assistance of Étienne Audet-Walsh, Dominique Lavallée and Nathalie Morin at the Station aquicole de l'ISMER. We would like to thank Claude Pelletier from IRZC (Shippagan, N. B., Canada) for his helpful assistance in lipid analysis.

\section{References}

AOCS (1989) American Oil Chemist's Society Official Method Ce 1b-89, Official Methods and Recommended Practices of the American Oil Chemist's Society. AOCS Press, Champain, IL.

Asfie, M., Yoshijima, T. \& Sugita, H. (2003) Characterization of the goldfish fecal microflora by the fluorescent in situ hybridization method. Fish. Sci., 69, 21-26.

Bell, J.G., Castell, J.D., Tocher, D.R., Macdonald, F.M. \& Sargent, J.R. (1995) Effects of different dietary arachidonic acid - docosahexaenoic acid ratios on phospholipid fatty acid compositions and prostaglandin production in juvenile turbot (Scophthalmus maximus). Fish Physiol. Biochem., 14, 139-151.

Bell, J.G. \& Sargent, J.R. (2003) Arachidonic acid in aquaculture feeds: current status and future opportunities. Aquaculture, 218, 491-499. 
Ben Khemis, I., de la Noue, J. \& Audet, C. (2000) Feeding larvae of winter flounder Pleuronectes americanus (Walbaum) with live prey or microencaspsulated diet: linear growth and protein, RNA and DNA content. Aquac. Res., 31, 377-386.

Bessonart, M., Izquierdo, M.S., Salhi, M., Hernandez-Cruz, C.M., Gonzalez, M.M. \& FernandezPalacios, H. (1999) Effect of dietary arachidonic acid levels on growth and survival of gilthead sea bream (Sparus aurata L.) larvae. Aquaculture, 179, 265-275.

Bransden, M. P., Cobcroft, J. M., Battaglene, S. C., Dunstan, G. A., Nichols, P.D. \& Bell, J. G. (2004) Dietary arachidonic acid alters tissue fatty acid profile, whole body eicosanoid production and resistance to hypersaline challenge in larvae of the temperate marine fish, striped trumpeter (Latris lineata). Fish Physiol. Biochem., 30, 241-256.

Castell JD, Bell JG, Tocher DR, Sargent JR (1994) Effects of purified diets containing different combinations of arachidonic and docosahexaenoic acid on survival, growth and fatty acid composition of juvenile turbot (Scophthalmus maximus). Aquaculture 128:315-333.

Copeman, L.A. \& Parrish, C.C. (2002) Lipid composition of malpigmented and normally pigmented newly settled yellowtail founder, Limanda ferruginea (Storer). Aquac. Res., 33, $1209-1219$.

Eddy, S.D. \& Jones, S.H. (2002) Microbiology of summer flounder Paralichthys dentatus fingerling production at a marine fish hatchery. Aquaculture, 211, 9-28.

Folch, J., Lees, M. \& Sloane-Stanley, G.H. (1957) A simple method for the isolation and purification of total lipids from animal tissues. J. Biol. Chem., 226, 497-509.

Garcia, A.S., Parrish, C.C. \& Brown, J.A. (2008) Growth and lipid composition of Atlantic cod (Gadus morhua) larvae in response to differently enriched Artemia franciscana. Fish Physiol. Biochem., 34, 77-94. 
Hansen, G.H. \& Olafsen, J.A. (1999) Bacterial interactions in early life stages of marine cold water fish. Microb. Ecol., 38, 1-26.

Hjelm, M., Berg, Ø., Riaza, A., Nielsen, J., Melchiorsen, J., Jensen, S., Duncan, H., Ahrens, P., Birkbeck, H. \& Gram, L. (2004) Selection and identification of autochthonous potential probiotic bacteria from turbot larvae (Scophthalmus maximus) rearing units. Syst. Appl. Microbiol., 27, 360-371.

Hjörleifsson, E. \& Klein-MacPhee, G. (1992) Estimation of live standard length of winter flounder Pleuronectes americanus larvae from formalin-preserved, ethanol-preserved and frozen specimens. Mar. Ecol. Prog. Ser., 82, 13-19.

Jensen, S., Ovreas, L., Bergh, O. \& Torsvik, V. (2004) Phylogenetic analysis of bacterial communities associated with larvae of the Atlantic halibut propose succession from a uniform normal flora. Syst. Appl. Microbiol., 27, 728-736.

Kiron, V., Fukuda, H., Takeuchi, T. \& Watanabe, T. (1995) Essential fatty acid nutrition and defence mechanisms in rainbow trout Oncorhynchus mykiss. Comp. Biochem. Physiol., A: Mol. Integr. Physiol., 111A, 361-367.

Korsnes, K., Nicolaisen, O., Skår, C.K., Nerland, A.H. \& Bergh, Ø. (2006) Bacteria in the gut of juvenile cod Gadus morhua fed live feed enriched with four different commercial diets. ICES J. Mar. Sci., 63, 296-301.

Koven, W., Barr, Y., Lutzky, S., Ben-Atia, I., Weiss, R., Harel, M., Behrens, P. \& Tandler, A. (2001) The effect of dietary arachidonic acid (20:4n-6) on growth, survival and resistance to handling stress in gilthead seabream (Sparus aurata) larvae. Aquaculture, 193, 107-122.

Laurence, G. C. (1977) A bioenergetic model for the analysis of feeding and survival potential of winter flounder, Pseudopleuronectes americanus, larvae during the period from hatching to metamorphosis. Fish. Bull., 75, 529-546. 
Lebaron, P., Servais, P., Baudoux, A.-C., Bourrain, M., Courties, C. \& Parthuisot, N. (2002) Variations of bacterial-specific activity with cell size and nucleic acid content assessed by flow cytometry. Aquat. Microb. Ecol., 28, 131-140.

Makridis, P., Jon Fjellheim, A., Skjermo, J. \& Vadstein, O. (2000) Control of the bacterial flora of Brachionus plicatilis and Artemia franciscana by incubation in bacterial suspensions. Aquaculture, 185, 207-218.

Montero, D., Socorro, J., Tort, L., Caballero, M.J., Robaina, L.E., Vergara, J.M. \& Izquierdo, M.S. (2004) Glomerulonephritis and immunosuppression associated with dietary essential fatty acid deficiency in gilthead sea bream, Sparus aurata L., juveniles. J. Fish Dis., 27, 297-306.

Munro, P.D., Barbour, A. \& Birkbeck, T.H. (1994) Comparison of the gut bacterial-flora of startfeeding larval turbot reared under different conditions. J. Appl. Bacteriol., 77, 560-566.

Murray, H.M., Gallant, J.W., Perez-Casanova, J.C., Johnson, S.C., Douglas, S.E., 2003a. Ontogeny of lipase expression in winter flounder. Journal of Fish Biology 62, 816-833.

Muroga, K. (1987) The isolation of intestinal microflora of farmed red seabream (Pagrus major) and black seabream (Acanthopagrus schlegeli) at larval and juvenile stages. Aquaculture, $65,79-88$.

Nicolas, J. (1989) Bacterial flora associated with a trophic chain consisting of microalgae, rotifers and turbot larvae: Influence of bacteria on larval survival. Aquaculture, 83, 237-248.

Olafsen, J.A. (2001) Interactions between fish larvae and bacteria in marine aquaculture. Aquaculture, 200, 223-247.

Olsen, A.I., Attramadal, Y., Jensen, A. \& Olsen, Y. (1999) Influence of size and nutritional value of Artemia franciscana on growth and quality of halibut larvae (Hippoglossus hippoglossus) during the live feed period. Aquaculture, 179, 475-487. 
Olsen, A.I., Olsen, Y., Attramadal, Y., Christie, K., Birkbeck, T.H., Skjermo, J. \& Vadstein, O. (2000) Effects of short term feeding of microalgae on the bacterial flora associated with juvenile Artemia franciscana. Aquaculture, 190, 11-25.

Olsson, J.C., Joborn, A., Westerdahl, A., Blomberg, L., Kjelleberg, S. \& Conway, P.L. (1998) Survival, persistence and proliferation of Vibrio anguillarum in juvenile turbot, Scophthalmus maximus (L.), intestine and feces. J. Fish Dis., 21, 1-9.

Park, H. G., Puvanendran, V., Kellett, A., Parrish, C. C. \& Brown, J. A. (2006) Effect of enriched rotifers on growth, survival, and composition of larval Atlantic cod (Gadus morhua). ICES J. Mar. Sci., 63, 285-295.

Parrish, C. C., Whiticar, M., \& Puvanendran, V. (2007) Is w6 docosapentaenoic acid an essential fatty acid during early ontogeny in marine fauna? Limnol. Oceanogr., 52, 476-479.

Parrish, C. C. (1999) Determination of total lipid, lipid classes, and fatty acids in aquatic samples. In: Lipids in freshwater ecosystems (Arts, M. T. \& Wainman, B. C., eds.), pp. 5-20. Springer-Verlag, New York.

Pernet, F., Pelletier, C. \& Milley, J. (2006) Comparison of three solid-phase extraction methods for fatty acid analysis of lipid fractions in tissues of marine bivalves. J. Chromatogr., 1137, $127-137$.

Plante, S., Pernet, F., Haché, R., Ritchie, R., Ji, B. \& McIntosh, D. (2007) Ontogenetic variations in lipid class and fatty acid composition of haddock larvae Melanogrammus aeglefinus in relation to changes in diet and microbial environment. Aquaculture, 263, 107-121.

Rainuzzo, J.R., Reitan, K.I. \& Olsen, Y. (1994) Lipid composition in turbot larvae fed live feed cultured by emulsion of different lipid classes. Comp. Biochem. Physiol. A, 107, 699-710.

Reitan, K.I., Matvik, C.M. \& Vadstein, O. (1998) Drinking rate, uptake of bacteria and microalgae in turbot larvae. J. Fish Biol., 53, 1145-1154. 
Reitan, K.I., Rainuzzo, J.R. \& Olsen, Y. (1994) Influence of lipid composition of live feed on growth, survival and pigmentation of turbot larvae. Aquac. Int., 2, 33-48.

Ringø, E. \& Birkbeck, T.H. (1999) Intestinal microflora of fish larvae and fry: A review. Aquac. Res., 30, 73-93.

Ringø, E., Birkbeck, T.H., Munro, P.D., Vadstein, O. \& Hjelmeland, K. (1996) The effect of early exposure to Vibrio pelagius on the aerobic bacterial flora of turbot, Scophthalmus maximus (L.) larvae. J. Appl. Bacteriol., 81, 207-211.

Ritar, A. J., Dunstan, G. A., Nelson, M. N., Brown, M. R., Nichols, P. D., Thomas, C. W., Smith, E. G., Crear, B. J. \& Kolkovski, S. (2004) Nutritional and bacterial profiles of juvenile Artemia fed different enrichments and during starvation. Aquaculture, 239, 351-373.

Salvesen, I., Skjermo, J. \& Vadstein, O. (1999) Growth of turbot (Scophthalmus maximus L.) during first feeding in relation to the proportion of $\mathrm{r} / \mathrm{K}$-strategists in the bacterial community of the rearing water. Aquaculture, 175, 337-350.

Sargent, J.R., Tocher, D.R. \& Bell, J.G. (2002) The lipids. In: Fish nutrition (Halver, J.E. \& Hardy, R.W., eds.), 3rd edn, pp. 181-255. Academic Press, Amsterdam.

Sheldon, V.M. \& Blazer, V.S. (1991) Influence of dietary lipid and temperature on bactericidal activity of channel catfish macrophages. J. Aquat. Anim. Health, 3, 87-93.

Skjermo, J. \& Vadstein, O. (1993) Characterization of the bacterial flora of mass cultivated Brachionus plicatilis. Hydrobiologia, 255-256, 185-191.

Skjermo, J. \& Vadstein, O. (1999) Techniques for microbial control in the intensive rearing of marine larvae. Aquaculture, 177, 333-343.

Støttrup, J.G. \& McEvoy, L.A. (2003) Live feeds in marine aquaculture, Blackwell Science, Oxford, $318 \mathrm{p}$. 
Tanasomwang, V. \& Muroga, K. (1988) Intestinal microflora of larval and juvenile stages in Japanese flounder (Paralichthys olivaceus). Fish Pathology 23, 77-83.

Tanasomwang, V. \& Muroga, K. (1989) Intestinal microflora of rockfish Sebastes schlegeli, tiger puffer Takifugu rubripes and red grouper Epinephelus akaara at their larval and juvenile stages. Nippon Suisan Gakkaishi, 55, 1371-1377.

Tocher, D.R. (2003) Metabolism and functions of lipids and fatty acids in teleost fish. Rev. Fish. Sci., 11, 107-184.

Tytler, P. (1988) Drinking in yolk-sac stage larvae of the halibut, Hippoglossus hippoglossus (L.). J. Fish Biol., 32, 493-494.

Vadstein, O. (1997) The use of immunostimulation in marine larviculture: possibilities and challenges. Aquaculture, 155, 405-421.

Vadstein, O., Mo, T.A. \& Bergh, Ø. (2004) Microbial interactions, prophylaxis and diseases. In: Culture of cold-water marine fish (Moksness, E., Kjørsvik, E. \& Olsen, Y., Eds.), pp. 2872, Blackwell Scientific Publications Ltd., Oxford.

Vaillancourt, R. (2008) Contribution à l'optimisation des conditions d'élevage du stade larvaire de la plie rouge (Pseudopleuronectes americanus). $\mathrm{Ph}$. D. Thesis. Université du Québec à Rimouski, Rimouski (Qué.), Canada, 149 p.

Verdonck, L., Grisez, L., Sweetman, E., Minkoff, G., Sorgeloos, P., Ollevier, F. \& Swings, J. (1997) Vibrios associated with routine productions of Brachionus plicatilis. Aquaculture, $149,203-214$.

Verschuere, L. (1997) Monitoring Biolog patterns and r/K-strategists in the intensive culture of Artemia juveniles. J. Appl. Microbiol., 83, 603-612.

Willey, S., Bengtson, D.A. \& Harel, M. (2003) Arachidonic acid requirements in larval summer flounder, Paralichthys dentatus. Aquac. Int., 11, 131-149. 
Zar, J. H. (1999) Biostatistical analysis, 4th edn., Prentice Hall, New Jersey, USA, 929 p. 
Table 1 Lipid classes and selected fatty acid composition (mean $\pm \mathrm{SD}, \mathrm{n}=3$ ) of enriched rotifers. Enrichment diets were Culture Selco (SEL), DHA protein Selco (DPS) and Algamac $2000(A L G)$. Data were obtained in our laboratory (Vaillancourt, 2008).

\begin{tabular}{lccc}
\hline & $S E L$ & $D P S$ & $A L G$ \\
\hline Total lipids & & & \\
$\left(\mathrm{mg} \mathrm{g}^{-1}\right.$ wet weight $)$ & $11.9 \pm 6.1$ & $21.7 \pm 3.9$ & $16.4 \pm 7.3$
\end{tabular}

Lipid class

(\% of total lipids)

$\begin{array}{rccc}\text { Steryl/wax esters } & 2 \pm 3^{\mathrm{a}} & 5 \pm 4^{\mathrm{ab}} & 7 \pm 4^{\mathrm{ab}} \\ \text { Triacylglycerols } & 31 \pm 6 & 44 \pm 15 & 32 \pm 10 \\ \text { Free fatty acids } & 14 \pm 12 & 6 \pm 8 & 13 \pm 10 \\ \text { Sterols } & 5 \pm 5 & 4 \pm 6 & 4 \pm 3\end{array}$

Acetone mobile

$\begin{array}{rrrr}\text { polar lipids } & 21 \pm 10 & 14 \pm 12 & 14 \pm 7 \\ \text { Phospholipids } & 13 \pm 3^{\mathrm{ab}} & 17 \pm 40^{\mathrm{b}} & 8 \pm 3^{\mathrm{a}}\end{array}$

Selected fatty acids

(\% of total fatty acids)

$\begin{array}{lccc}\sum \text { SFA } & 22.7 \pm 3.8^{\mathrm{a}} & 25.0 \pm 0.9^{\mathrm{a}} & 34.7 \pm 4.0^{\mathrm{b}} \\ \sum \text { MUFA } & 47.6 \pm 3.2^{\mathrm{c}} & 32.6 \pm 1.6^{\mathrm{b}} & 17.8 \pm 4.9^{\mathrm{a}} \\ \sum \text { PUFA } & 37.1 \pm 0.8 & 48.3 \pm 10.0 & 59.3 \pm 16.9 \\ \text { AA } & 1.1 \pm 1.0 & 1.9 \pm 0.2 & 3.8 \pm 0.5 \\ \text { EPA } & 11.1 \pm 6.7 & 7.2 \pm 0.4 & 6.8 \pm 2.5 \\ \text { DHA } & 5.8 \pm 3.8^{\mathrm{ab}} & 12.9 \pm 1.3^{\mathrm{bc}} & 21.1 \pm 6.1^{\mathrm{c}} \\ \text { DHA:EPA } & 0.5 \pm 0.0^{\mathrm{a}} & 1.8 \pm 0.1^{\mathrm{ab}} & 3.2 \pm 1.1^{\mathrm{b}} \\ \text { EPA:AA } & 15.6 \pm 19.2 & 3.8 \pm 0.1 & 1.8 \pm 0.5\end{array}$

Different superscript letters indicate significant differences among diets $(P<0.05)$. 
Table 2 Bacterial colonization in intestinal lumen (bacteria $\mathrm{mm}^{-2}$ ) and on gills and fins (\% bacteria area/tissue area observed) of winter flounder larvae at 26 days post-hatching that had been fed rotifers enriched with three commercial diets: AlgaMac 2000 $(A L G)$, DHA protein Selco (DPS), and Selco $3000(S E L)$. Two larval tanks were used for each type of rotifer enrichment. The asterisk indicates significant difference among treatments.

\begin{tabular}{cccc}
\hline & $A L G$ & $D P S$ & $S E L$ \\
Intestinal lumen & $870 \pm 1265^{*}$ & $3544 \pm 2415$ & $6541 \pm 7308$ \\
Gills & $3.9 \pm 6.7$ & $1.9 \pm 1.8$ & $2.9 \pm 3.3$ \\
Fins & $23 \pm 15.2$ & $22.4 \pm 12.5$ & $24.9 \pm 13.0$ \\
\hline
\end{tabular}


Table 3 Lipid class contents presented as \% weight of total lipids (mean \pm SD) of winter flounder larvae fed with rotifers raised on one of three media treatments (AlgaMac $2000[A L G]$, DHA protein Selco $[D P S]$ and Selco $3000[S E L])$. Two larval tanks were used for each type of rotifer enrichment. Different superscript letters indicate significant differences among treatments for a given sampling day $(P<0.05)$. dph: days post-hatching.

\begin{tabular}{|c|c|c|c|c|}
\hline $\mathrm{dph}$ & Treatment & Triacylglycerol & Sterol & Phospholipid \\
\hline & $A L G$ & $0.9 \pm 1.0$ & $7.6 \pm 3.9$ & $87.7 \pm 2.3$ \\
\hline & $D P S$ & $2.1 \pm 2.5$ & $7.0 \pm 3.3$ & $85.5 \pm 3.4$ \\
\hline \multirow[t]{3}{*}{4} & SEL & $3.6 \pm 1.3$ & $11.1 \pm 10.2$ & $82.1 \pm 13.0$ \\
\hline & $A L G$ & $1.4 \pm 1.7$ & $8.6 \pm 5.4$ & $86.2 \pm 7.0$ \\
\hline & $D P S$ & $1.9 \pm 1.3$ & $8.3 \pm 3.0$ & $88.6 \pm 4.9$ \\
\hline \multirow[t]{3}{*}{15} & SEL & $0.9 \pm 1.0$ & $8.2 \pm 3.6$ & $88.7 \pm 5.2$ \\
\hline & $A L G$ & $8.7 \pm 5.1$ & $8.5 \pm 2.8$ & $80.9 \pm 7.0$ \\
\hline & $D P S$ & $5.8 \pm 2.8$ & $8.1 \pm 2.9$ & $84.6 \pm 5.3$ \\
\hline \multirow[t]{3}{*}{26} & SEL & $3.2 \pm 0.8$ & $8.9 \pm 3.4$ & $87.0 \pm 4.5$ \\
\hline & $A L G$ & $19.0 \pm 4.5$ & $9.7 \pm 2.8$ & $65.8 \pm 11.4$ \\
\hline & $D P S$ & $15.1 \pm 3.5$ & $9.7 \pm 2.0$ & $66.3 \pm 11.4$ \\
\hline \multirow[t]{3}{*}{38} & $S E L$ & $15.1 \pm 3.5$ & $9.9 \pm 3.1$ & $70.3 \pm 8.9$ \\
\hline & $A L G$ & $24.5 \pm 4.1^{b}$ & $9.6 \pm 2.3$ & $62.5 \pm 10.7$ \\
\hline & $D P S$ & $21.9 \pm 4.1^{\mathrm{b}}$ & $11.4 \pm 2.2$ & $62.6 \pm 9.3$ \\
\hline 46 & $S E L$ & $13.6 \pm 4.0^{\mathrm{a}}$ & $10.5 \pm 3.2$ & $74.0 \pm 8.2$ \\
\hline
\end{tabular}


Table 4 Selected fatty acid contents $(\%$ of TFA \pm SD) in neutral and polar lipids of winter flounder larvae fed one of three rotifer enrichments until 26 days post-hatching (dph): AlgaMac $2000(A L G)$, DHA protein Selco (DPS) and Selco 3000 (SEL). Two larval tanks were used for each type of rotifer enrichment. Different superscript letters indicate significant differences among treatments for a given sampling day $(P<$ $0.05)$.

\begin{tabular}{|c|c|c|c|c|c|c|c|}
\hline \multirow[b]{2}{*}{ Fatty acid } & \multirow[b]{2}{*}{ dph } & \multicolumn{3}{|c|}{ Neutral lipids } & \multicolumn{3}{|c|}{ Polar lipids } \\
\hline & & $A L G$ & $D P S$ & SEL & $A L G$ & $D P S$ & $S E L$ \\
\hline \multirow[t]{3}{*}{$16: 0$} & 4 & $19.0 \pm 5.0$ & $16.3 \pm 0.3$ & $15.8 \pm 0.3$ & $24.4 \pm 0.6$ & $23.4 \pm 0.1$ & $23.3 \pm 0.1$ \\
\hline & 26 & $14.1 \pm 0.1$ & $14.1 \pm 2.9$ & $12.2 \pm 0.0$ & $21.8 \pm 0.1$ & $19.3 \pm 0.5$ & $18.0 \pm 0.5$ \\
\hline & 46 & $9.2 \pm 0.1$ & $9.5 \pm 0.1$ & $10.1 \pm 0.7$ & $16.3 \pm 0.4$ & $16.3 \pm 0.3$ & $16.1 \pm 0.2$ \\
\hline \multirow[t]{3}{*}{ 18:0 } & 4 & $8.9 \pm 0.6$ & $8.6 \pm 0.5$ & $8.0 \pm 0.1$ & $8.9 \pm 0.7$ & $8.5 \pm 0.2$ & $8.7 \pm 0.3$ \\
\hline & 26 & $5.0 \pm 0.9$ & $5.6 \pm 0.9$ & $7.2 \pm 0.1$ & $7.5 \pm 0.6$ & $7.6 \pm 0.4$ & $8.7 \pm 0.2$ \\
\hline & 46 & $5.1 \pm 0.3$ & $6.0 \pm 0.2$ & $6.8 \pm 0.8$ & $6.9 \pm 0.3$ & $7.0 \pm 0.2$ & $7.2 \pm 0.1$ \\
\hline \multirow[t]{3}{*}{$16: 1 n-7$} & 4 & $1.8 \pm 0.2$ & $2.9 \pm 1.1$ & $2.5 \pm 0.0$ & $1.7 \pm 0.3$ & $1.9 \pm 0.1$ & $1.9 \pm 0.1$ \\
\hline & 26 & $10.0 \pm 2.6$ & $11.0 \pm 3.2$ & $11.0 \pm 0.2$ & $4.0 \pm 0.3$ & $4.8 \pm 0.8$ & $6.0 \pm 0.2$ \\
\hline & 46 & $3.2 \pm 0.1$ & $3.2 \pm 0.2$ & $2.9 \pm 0.1$ & $1.9 \pm 0.1$ & $1.9 \pm 0.2$ & $1.9 \pm 0.1$ \\
\hline \multirow[t]{3}{*}{ 18:1n-9 } & 4 & $11.8 \pm 1.9$ & $14.3 \pm 1.5$ & $14.1 \pm 0.4$ & $10.4 \pm 0.3$ & $9.6 \pm 0.3$ & $10.2 \pm 0.4$ \\
\hline & 26 & $4.6 \pm 0.2$ & $13.9 \pm 0.1$ & $14.6 \pm 0.0$ & $5.3 \pm 0.1$ & $11.1 \pm 0.2$ & $13.2 \pm 0.1$ \\
\hline & 46 & $19.9 \pm 0.3$ & $20.3 \pm 0.1$ & $19.4 \pm 0.7$ & $15.6 \pm 0.8$ & $15.9 \pm 0.2$ & $15.9 \pm 0.0$ \\
\hline \multirow[t]{3}{*}{$18: 1 n-7$} & 4 & $2.5 \pm 1.1$ & $3.1 \pm 0.9$ & $3.3 \pm 0.3$ & $3.0 \pm 0.1$ & $3.1 \pm 0.3$ & $3.0 \pm 0.2$ \\
\hline & 26 & $5.9 \pm 0.8$ & $3.9 \pm 0.2$ & $4.8 \pm 0.1$ & $5.5 \pm 0.0$ & $4.2 \pm 0.4$ & $4.8 \pm 0.2$ \\
\hline & 46 & $8.1 \pm 0.3$ & $8.5 \pm 0.2$ & $8.1 \pm 0.3$ & $6.6 \pm 0.0$ & $6.5 \pm 0.0$ & $6.3 \pm 0.1$ \\
\hline \multirow[t]{3}{*}{$24: 1 n-7$} & 4 & $4.5 \pm 0.4$ & $4.1 \pm 1.1$ & $5.8 \pm 0.0$ & $1.5 \pm 2.1$ & $2.2 \pm 0.4$ & $2.7 \pm 0.2$ \\
\hline & 26 & $2.4 \pm 0.2$ & $2.3 \pm 1.1$ & $3.6 \pm 0.2$ & $1.0 \pm 0.1$ & $0.8 \pm 0.3$ & $1.1 \pm 0.1$ \\
\hline & 46 & $0.1 \pm 0.1$ & $0.3 \pm 0.0$ & $0.9 \pm 0.8$ & $0.1 \pm 0.0$ & $0.3 \pm 0.0$ & $0.6 \pm 0.4$ \\
\hline $18: 2 n-6$ & 4 & $3.9 \pm 0.2$ & $5.1 \pm 1.1$ & $4.0 \pm 0.2$ & $3.5 \pm 0.3$ & $3.5 \pm 0.4$ & $3.5 \pm 0.1$ \\
\hline \multirow[t]{2}{*}{ cis } & 26 & $1.6 \pm 0.3$ & $5.6 \pm 0.1$ & $5.0 \pm 0.0$ & $1.0 \pm 0.1$ & $4.4 \pm 0.1$ & $5.4 \pm 0.1$ \\
\hline & 46 & $5.6 \pm 0.7$ & $5.6 \pm 0.0$ & $5.5 \pm 0.0$ & $7.4 \pm 0.3$ & $7.8 \pm 0.1$ & $7.9 \pm 0.3$ \\
\hline \multirow[t]{3}{*}{$18: 3 n-3$} & 4 & $0.0 \pm 0.0$ & $2.2 \pm 0.4$ & $1.3 \pm 0.3$ & $0.7 \pm 0.0$ & $1.0 \pm 0.3$ & $0.8 \pm 0.1$ \\
\hline & 26 & $0.2 \pm 0.2$ & $0.7 \pm 0.1$ & $1.0 \pm 0.0$ & $0.1 \pm 0.1$ & $0.3 \pm 0.0$ & $0.6 \pm 0.1$ \\
\hline & 46 & $25.6 \pm 0.2$ & $24.6 \pm 0.4$ & $22.2 \pm 1.2$ & $18.6 \pm 0.0$ & $18.4 \pm 0.2$ & $18.0 \pm 0.9$ \\
\hline \multirow[t]{3}{*}{$22: 5 n-6$} & 4 & $0.0 \pm 0.0$ & $0.1 \pm 0.2$ & $0.1 \pm 0.1$ & $0.0 \pm 0.0$ & $0.3 \pm 0.4$ & $0.2 \pm 0.3$ \\
\hline & 26 & $7.1 \pm 0.6$ & $0.4 \pm 0.1$ & $0.2 \pm 0.0$ & $6.7 \pm 0.3$ & $0.3 \pm 0.4$ & $0.4 \pm 0.0$ \\
\hline & 46 & $0.3 \pm 0.0$ & $0.0 \pm 0.0$ & $0.0 \pm 0.0$ & $1.3 \pm 0.3$ & $0.2 \pm 0.0$ & $0.1 \pm 0.1$ \\
\hline \multirow[t]{3}{*}{$22: 5 n-3$} & 4 & $1.9 \pm 0.3$ & $2.1 \pm 0.6$ & $1.6 \pm 0.1$ & $1.3 \pm 0.1$ & $1.4 \pm 0.1$ & $1.4 \pm 0.1$ \\
\hline & 26 & $3.5 \pm 0.2$ & $4.5 \pm 0.4$ & $4.7 \pm 0.2$ & $2.8 \pm 0.4$ & $5.9 \pm 0.1$ & $6.4 \pm 0.1$ \\
\hline & 46 & $0.2 \pm 0.0$ & $0.4 \pm 0.0$ & $0.2 \pm 0.3$ & $0.8 \pm 0.0$ & $1.4 \pm 0.3$ & $1.5 \pm 0.1$ \\
\hline \multirow[t]{3}{*}{$20: 4 n-6$} & 4 & $2.3 \pm 0.4$ & $2.5 \pm 0.6$ & $2.4 \pm 0.0$ & $4.6 \pm 2.4$ & $3.6 \pm 0.7$ & $3.5 \pm 0.6$ \\
\hline & 26 & $6.7 \pm 0.6$ & $3.8 \pm 0.7$ & $3.3 \pm 0.1$ & $7.6 \pm 0.4$ & $6.5 \pm 0.8$ & $5.7 \pm 0.7$ \\
\hline & 46 & $2.7 \pm 0.1$ & $1.0 \pm 0.0$ & $1.2 \pm 0.5$ & $3.1 \pm 0.0$ & $2.7 \pm 0.0$ & $2.7 \pm 0.1$ \\
\hline \multirow[t]{2}{*}{$20: 5 n-3$} & 4 & $10.1 \pm 1.6$ & $10.5 \pm 1.5$ & $8.9 \pm 0.1$ & $11.4 \pm 0.5$ & $11.7 \pm 0.2$ & $11.4 \pm 0.8$ \\
\hline & 26 & $8.4 \pm 0.8$ & $8.8 \pm 0.3$ & $6.9 \pm 0.3$ & $6.1 \pm 0.3$ & $9.9 \pm 1.3$ & $9.2 \pm 0.0$ \\
\hline
\end{tabular}




\begin{tabular}{lccccccr} 
& 46 & $2.0 \pm 0.1$ & $2.3 \pm 0.1$ & $2.6 \pm 0.7$ & $5.1 \pm 0.0$ & $6.1 \pm 0.4$ & $6.0 \pm 0.0$ \\
$22: 6 n-3$ & 4 & $19.6 \pm 4.0$ & $20.0 \pm 1.2$ & $20.5 \pm 0.4$ & $22.2 \pm 0.6$ & $23.3 \pm 1.0$ & $22.5 \pm 1.4$ \\
& 26 & $17.2 \pm 0.5$ & $8.8 \pm 3.4$ & $5.8 \pm 0.1$ & $23.9 \pm 1.7$ & $15.7 \pm 2.6$ & $9.0 \pm 0.3$ \\
& 46 & $0.7 \pm 0.0$ & $0.7 \pm 0.3$ & $1.3 \pm 1.1$ & $4.5 \pm 1.0$ & $3.6 \pm 0.1$ & $2.3 \pm 0.8$ \\
SFA & 4 & $34.1 \pm 3.9^{\mathbf{b}}$ & $27.5 \pm 0.2^{\mathbf{a}}$ & $27.2 \pm 0.4^{\mathbf{a b}}$ & $35.2 \pm 2.2$ & $33.7 \pm 0.0$ & $34.1 \pm 0.9$ \\
& 26 & $25.1 \pm 0.6^{\mathbf{b}}$ & $24.2 \pm 3.2^{\mathbf{a}}$ & $24.0 \pm 0.4^{\mathbf{a b}}$ & $32.0 \pm 0.7$ & $28.9 \pm 0.0$ & $29.0 \pm 0.5$ \\
& 46 & $16.3 \pm 0.3$ & $17.2 \pm 0.2$ & $19.1 \pm 1.4$ & $24.5 \pm 0.7$ & $24.2 \pm 0.6$ & $24.7 \pm 0.4$ \\
MUFA & 4 & $23.8 \pm 5.3^{\mathbf{a}}$ & $27.7 \pm 4.7^{\mathbf{b}}$ & $30.8 \pm 1.0^{\mathbf{b}}$ & $19.7 \pm 0.8$ & $19.5 \pm 0.3$ & $20.9 \pm 0.7$ \\
& 26 & $27.0 \pm 0.7^{\mathbf{a}}$ & $39.3 \pm 1.6^{\mathbf{b}}$ & $44.2 \pm 0.5^{\mathbf{b}}$ & $17.2 \pm 0.2^{\mathbf{a}}$ & $24.5 \pm 0.7^{\mathbf{b}}$ & $29.6 \pm 0.4^{\mathbf{c}}$ \\
& 46 & $36.3 \pm 0.0^{\mathbf{a}}$ & $37.5 \pm 0.2^{\mathbf{a}}$ & $36.4 \pm 0.7^{\mathbf{a}}$ & $27.7 \pm 0.7$ & $28.2 \pm 0.2$ & $28.6 \pm 0.7$ \\
PUFA & 4 & $42.1 \pm 9.2^{\mathbf{b}}$ & $44.8 \pm 4.5^{\mathbf{a b}}$ & $42.0 \pm 0.6^{\mathbf{a}}$ & $45.0 \pm 1.4$ & $46.8 \pm 0.3$ & $44.9 \pm 1.6$ \\
& 26 & $47.9 \pm 0.1^{\mathbf{b}}$ & $36.5 \pm 4.8^{\mathbf{a b}}$ & $31.8 \pm 0.9^{\mathbf{a}}$ & $50.8 \pm 0.9^{\mathbf{b}}$ & $46.5 \pm 0.7^{\mathbf{a b}}$ & $41.4 \pm 0.1^{\mathbf{a}}$ \\
& 46 & $47.4 \pm 0.3^{\mathbf{b}}$ & $45.3 \pm 0.0^{\mathbf{a}}$ & $44.5 \pm 0.7^{\mathbf{a}}$ & $47.9 \pm 1.4$ & $47.6 \pm 0.3$ & $46.7 \pm 1.1$ \\
\hline
\end{tabular}




\section{Figure captions}

Figure 1 Figure 1. Histological slices of a winter flounder larva, 26 days post-hatching. (a) Gills: $\mathrm{A}=$ cartilage in gill arch; $\mathrm{B}=$ bacteria. (b) Intestine: $\mathrm{A}=$ enterocyte; $\mathrm{B}=$ bacteria; $C=$ brush border; $D=$ intestinal lumen. Scale bar $=10 \mu \mathrm{m}(1000 \times$, oil immersion).

Figure 2 Essential fatty acids $(\%$ of TFA \pm SD) in neutral and polar lipids in winter flounder larvae fed three rotifer enrichments $(\square$ AlgaMac $2000[A L G], \triangle$ DHA protein Selco [DPS], $\bigcirc$ Selco 3000 [SEL]) until 26 dph then weaned onto non-enriched Artemia and a dry diet (Lansy Cw). Two larval tanks were used for each type of rotifer enrichment. Asterisks indicate significant differences in fatty acid content in the indicated treatment on a given sampling day. Arrows on the $\mathrm{x}$-axes indicate the switch between rotifers and co-feeding and the horizontal dashed lines indicate the relative fatty acid level in the dry diet.

Figure 3 Total lengths of winter flounder larvae fed three rotifer enrichment media Algamac $2000[A L G] ; \mathbf{N}$ DHA protein Selco [DPS]; $\square$ Selco 3000 [SEL]) until 26 dph and then weaned onto Artemia and a dry diet (Lansy $\mathrm{Cw}$ ). Two larval tanks were used for each type of rotifer enrichment. Different letters indicate significant difference among larviculture treatments at a given day post-hatching. 
(a)
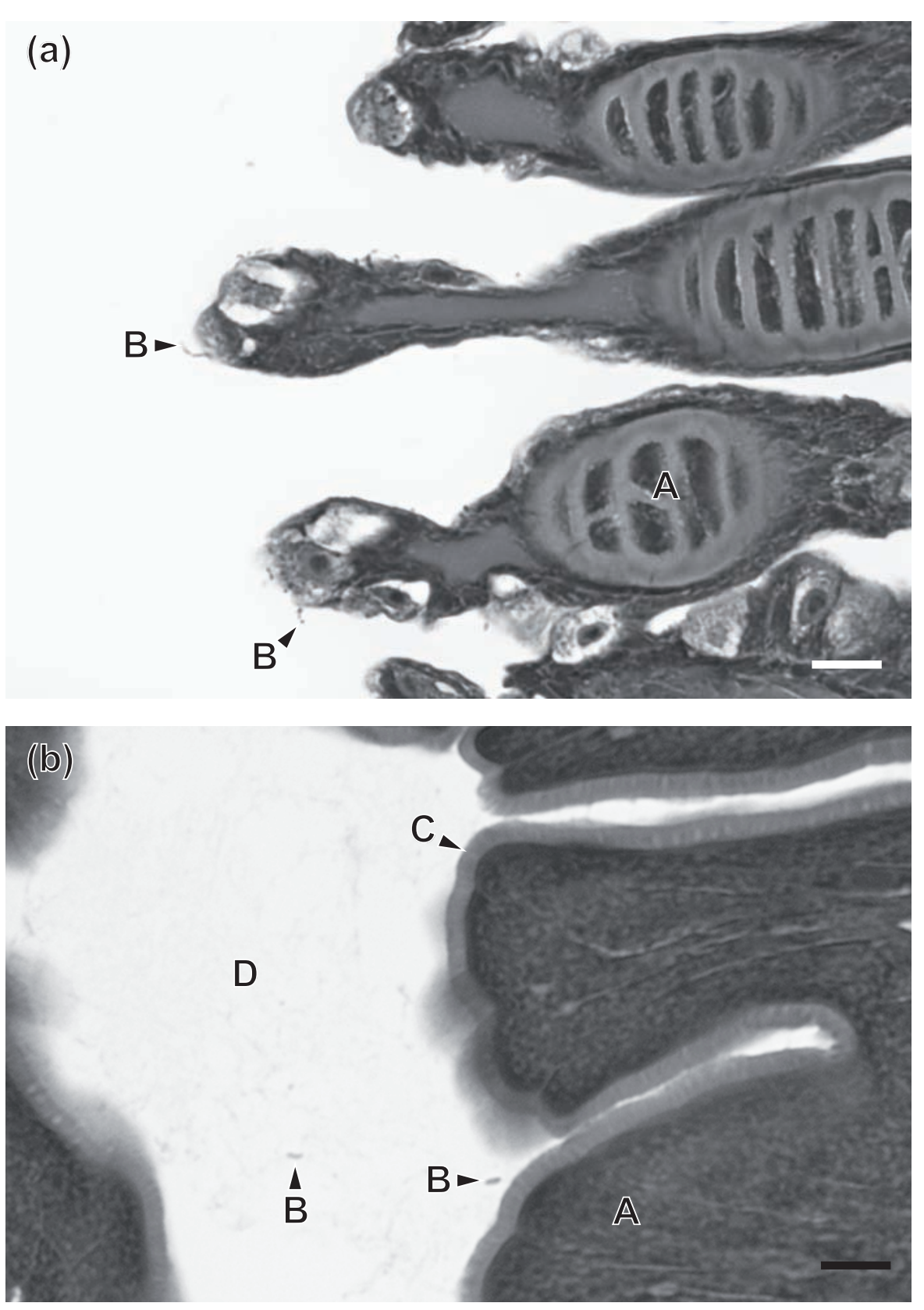

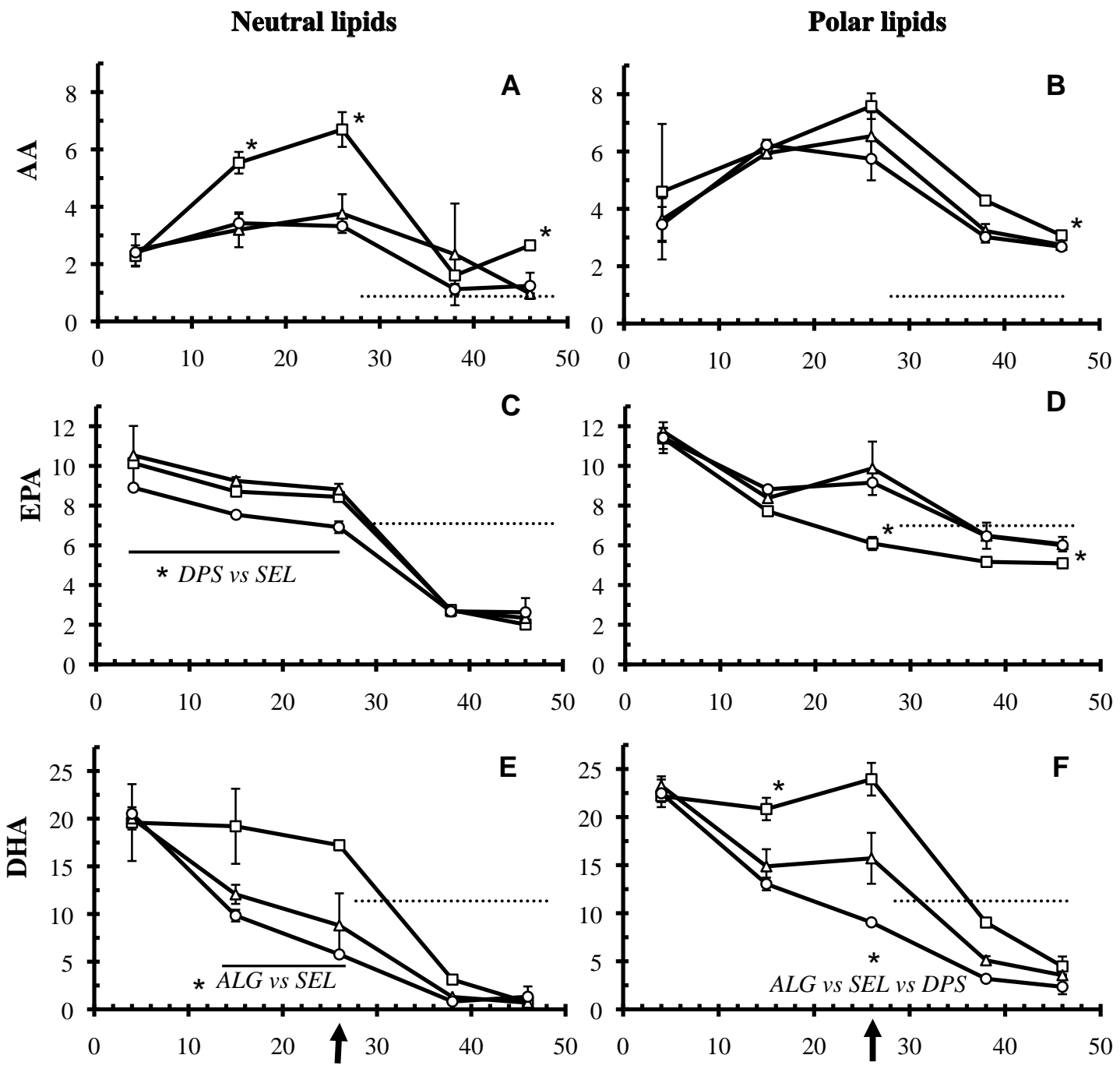

Day post-hatching

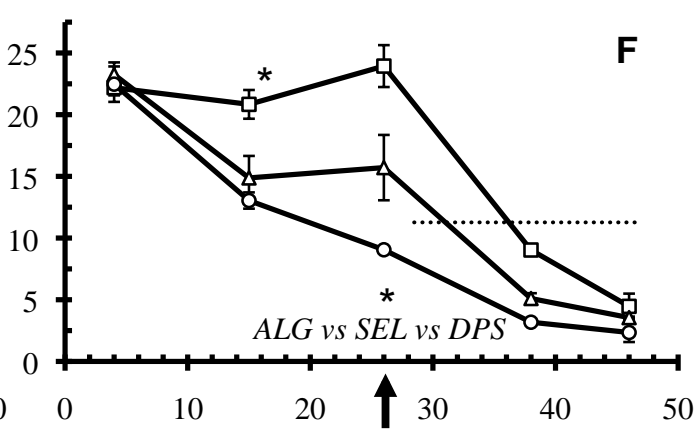

Day post-hatching 


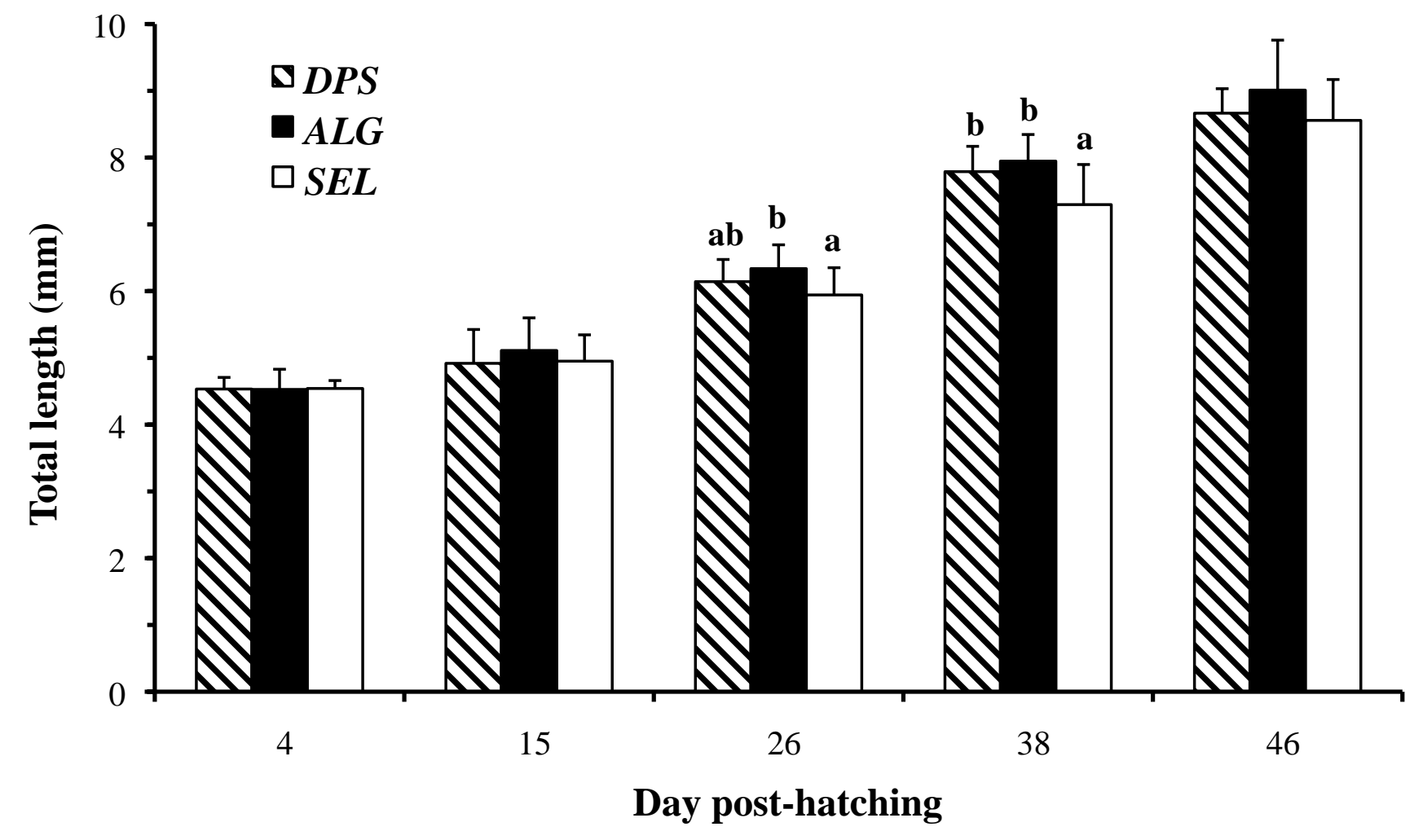

